\title{
Analyzing Sex Trafficking in Neo-Liberal Nigeria through Nigerian Women's Writings
}

\author{
Shalini Nadaswaran
}

\begin{abstract}
Human sex trafficking is a global plague, its magnitude staggering, robbing women of their sense of worth and dignity as human persons. With the case of Nigeria, the collapse of the post-colonial nation and the effects of neo-liberal policies have left the country steeped in corruption and poverty. A byproduct of this chaos is symptomatically reflected in the trafficking of Nigerian women into various parts of Europe and the United Kingdom, hoodwinked into fake job offers overseas to relieve their families from poverty. To understand the impact of such an unconscionable exploitation of Nigerian women as resources for the global capitalist flesh trade, a close qualitative analysis of literary novels, specifically Chika Unigwe's On Black Sisters' Street (2009), Akachi Ezeigbo's Trafficked (2008) and Abidemi Sanusi's Eyo (2009) in this paper will be used to demonstrate a representation of Nigerian female characters resisting the liminal spaces of sex trafficking they are forced into through their psychology of willfulness to access freedom. Also, the representations of these Nigerian female characters create an intricate web for us to understand the alarmingly systematic, highly regulated movement and exploitation of modern slavery. The results of this analysis demonstrate the female characters challenging their traffickers through their situation at their point zero space and escape to freedom, yet in their homecoming many turn to trafficking again due to high levels of poverty. Furthermore, Sanusi, Ezeigbo and Unigwe's writings ultimately serve as a conglomeration of literary works of protest that function as a clarion call to end the dehumanization of Nigerian women through sex trafficking.
\end{abstract}

Index Terms-Sex Trafficking, Nigerian Women, Neo-Liberal, Representation

\section{INTRODUCTION}

Sex trafficking has become a growing social issue where human beings have become commodities. In a neo-liberal state where economic freedom and liberalization are systems set in place to create an ostensibly more egalitarian society of equal resources and opportunities, this has been habituated to become a profit making industry by traffickers who use the false pretenses of better lives abroad to lure people who suffer high levels of poverty. Particularly with the context of Nigeria, the introduction of the Structural Adjustment Programs (SAPs) during the Babaginda regime inherited from the Obasanjo regime, opened the country to neo-liberal economic policies which did not grant ascendancy to the country's market forces but instead increased its international

Manuscript received November 9, 2011; revised December 28, 2011

Shalini Nadaswaran is with the School of English, Media and Performing Arts, Faculty of Arts and Social Sciences, University of New South Wales, Sydney, Australia. She is also under a fellowship scheme with the Department of English, Faculty of Arts and Social Sciences, University of Malaya, Kuala Lumpur, Malaysia (email: sha_nadaswaran@yahoo.com). debt, internal corruption, overvaluation of the naira, and decline into poverty. The optimism of economic growth that flourished during the initial years of independence and after the civil war dissipated after nearly thirty years of military dictatorship, indifferent political leaders and financial misgovernment which limited benefits for many people, making everyday living hard for most Nigerians. Estimated economic figures from 2005 show that 91 percent of Nigerians live under two dollars per day [1]. On the other hand, research shows that approximately " 40,000 to 50,000 Nigerian women have become victims of trafficking [sexual exploitation, forced labor, the removal of organs or servitude] over the past 15 years [1990-2005]", yet specific figures on Nigerian women forced into sex trafficking are unobtainable given the complex organizational infrastructure, migration routes and transit stays used to traffic victims [2]. This paper will argue how the effect of Nigeria's descent into a neo-liberal economic structure has left its women vulnerable to transnational crimes of human trafficking, commonly referred to as modern day slavery, specifically focusing on sex trafficking as a form of neo-liberal economic commodity. A comparative analysis of Abidemi Sanusi's Eyo (2009), Akachi Ezeigbo's Trafficked (2008) and Chika Unigwe's On Black Sisters' Street (2009) will give us a firsthand account on the business of trafficking women, the geographies of globalization that generate conditions for such trafficking as well as the reimaging of trafficking through resistance displayed by female characters who challenge the complex relations of power with their traffickers.

For this analysis we locate our discourse within the framework of womanist theory expounded by Chikewenye Okonjo Ogunyemi and Alice Walker. There are many varying epistemological positions in which Nigerian women's writings may be visibly situated, an accretion of theories such as African feminism, stiwanism (from STIWA: Social Transformation Including Women in Africa), Africana Womanism and so on which ultimately conglomerate towards expressions of various scholars' stances. Particularly confounding to this discussion is the location of African feminist theory within African women's writings. Although African feminist theorists like Carol Boyce Davies, and Susan Arndt articulate African feminism as a theory that combines feminist concerns with African concerns, the viability of African feminism is challenged by Africana womanist theorist Clenora Hudson-Weems who articulates the impossibility of amalgamating feminism into African concerns as feminism was "conceptualized and adopted by White women, involves an agenda that was designed to meet the needs and demands of that particular group" [3]. Although debatable, this perspective cannot be 
overlooked and we find first and second generation African women writers like Flora Nwapa, Ama Ata Aidoo, Buchi Emecheta and Mariama Ba themselves being defensive and indignant whenever they are referred to as feminist. Thus, embedded within the African female struggle for self-articulation, womanhood and empowerment is the greater battle to define evolving ideologies and theories which we hope is a process that will be progressively clarified and elucidated. As such, Ogunyemi and Walker's womanist theory is used in these Nigerian women's writings as a line of inquiry to examine the challenges post-independent Nigerian female characters face, theorizing the global magnitude of victimization faced by trafficked Nigerian women. Although Alice Walker's womanist theory draws on the African-American experience, we find her definition of womanist theory useful in providing a wholesome definition of the female quest for womanhood and empowerment. Moreover, it is relevant to use Walker's and Ogunyemi's discourse of womanist theory concurrently as their definitions overlap, implying a general concern for the development and self-definition of the Black female subject, in this context the resistance showed by trafficked Nigerian female characters as epitomizing the womanist process towards self-actualization and agency.

Before proceeding into the complexities of analyzing the points of resistance revealed through the representation of Nigerian female characters, it is important for us to return to a more general frame of reference, acknowledging the global scale of sex trafficking and the sheer immensity as well as intricate transnational network of organized crime that facilitates the smuggling, coercion, intimidation and violence against women and children. There are three main geographical regions where trafficking emerged and thrived from; "South Asia, Central and Eastern Europe, and East Asia" [4]. The recruitment of sex slaves from different regions of the world happen in different periods of time, based on a region's socio-economic and political situation. As such, professional traffickers prey on the destitution of women from these various areas and circumstances who long to provide better conditions of living for their families. These women are hoodwinked either by family friends or lured by false job advertisements that offer lucrative opportunities. While "trafficking networks have been able to offer young women the opportunity to travel [abroad] ... these offers involve varying degrees of fraud" that incarcerate the life of a recruited victim [5]. Thus, immense poverty and desire for survival is one of the key factors apart from global deprivation and discrimination that augmented the exploitation of women through the sex trade.

The magnitude of sex trafficking worldwide is staggering, the perverseness of selling women for immense profits shocking as it leaves a destructive trail in its path. Siddharth Kara's Sex Trafficking: Inside the Business of Modern Slavery (2009) argues profit numbers [...] indicate that trafficked sex slaves are by far the most lucrative slaves in the world. Only 4.2 percent of the world's slaves are trafficked sex slaves, but they generate 39.1 percent of slaveholders' profits [...] By comparison, Google's net profit margin in 2006 was 29.0 percent, and it is one of the most profitable companies in the United States. The same figure for
Microsoft was 28.5 percent; for Intel, 14.3 percent. General Electric posted 12.8 percent profit margin; ATandT, 11.7 percent; and Exxon Mobil, 10.8 percent. It may seem like a stretch to make direct comparisons between multinational corporations and ramshackle brothels, but the superficial point should be clear: Slave labor makes profits soar. [6] For this reason, the economics of sex trafficking has attracted crime syndicates all over the world into partaking of this burgeoning business. The economic profitability derived from this 'business' creates spontaneous, complex and sophisticated criminal networks that advance the transfer of women all over the globe. Profits acquired from 'transporting' women are kept solely by the exploiters while their victims continue to generate income for them. Kara's disconcerting comparison evidently places the senseless disregard for human dignity in perspective which we will later see communicated in Nigerian women's writings.

TABLE I: SELECTED DEMOGRAPHIC AND ECONOMIC INDICATORS OF NIGERIA

\begin{tabular}{|c|c|c|c|c|c|}
\hline \multirow[t]{5}{*}{ Figures } & Entire & Income Per & GDP Per & Average & Population \\
\hline & Population, & Capita, 2006 & Capita & Annual Rate & Living Under \\
\hline & 2010 & (Purchasing & Growth & of Inflation, & $\$ 2$ per day, \\
\hline & (millions) & Power Parity) & $1990-2005$ & 1990-2005 & 2005 \\
\hline & & & (Percent) & (Percent) & (Percent) \\
\hline \multirow[t]{8}{*}{ Nigeria } & 158.2 & 1,154 & 0.0 & 23 & 91 \\
\hline & Women as & Adult Literacy & Deportees for & Purchase & Price of \\
\hline & Percent of & Rate 2000 & prostitution & Price of & Sex Act \\
\hline & Labor Force & (Percent) & offences & Sex Slaves & (Euros) \\
\hline & & & from & in Italy & \\
\hline & & & Europe & (Euros) & \\
\hline & & & (1999 & & \\
\hline & & & $-2003)$ & & \\
\hline Nigeria & 37 & 72 & 19,774 & - & 20 \\
\hline $\begin{array}{l}\text { Sources: } \\
\text { ittp://eco } \\
\text { Migration } \\
\text { Modern S }\end{array}$ & $\begin{array}{l}\text { World B } \\
\text { n.worldbank } \\
\text { n 2007; Sidd } \\
\text { Slavery 2009; }\end{array}$ & $\begin{array}{l}\text { ank, online } \\
\text {.org; Toyin Fa } \\
\text { lharth Kara's } S \\
\text { tables } 3.1, \text { C. } 1\end{array}$ & $\begin{array}{l}\text { statistics } \\
\text { lola's The } \\
\text { ex Traffickin } \\
\text { and C. } 2 \text {. }\end{array}$ & $\begin{array}{l}\text { database, } \\
\text { Human Cos } \\
\text { lg: Inside th }\end{array}$ & $\begin{array}{l}\text { ailable at } \\
\text { of African } \\
\text { Business of }\end{array}$ \\
\hline
\end{tabular}

As tabulated in TABLE I, Nigeria's poverty, corruption, violence and criminal activities are some of the factors that hamper the nation's development. Such conditions are a perfect breeding ground within a neo-liberal context of supply and demand to forge human beings as commodities with high turnovers. Victor Opara places the business of sex trafficking in perspective when he states "as a result of Nigeria's oil resources, it is more economically viable than most African countries. Since poverty is a major reason why African women fall prey to trafficking, if an oil-rich country like Nigeria is unable to fend for its residents, it logically follows that most African countries would not be able to stop trafficking on their own" [7]. Statistics reveal that "against [the] backdrop [of deported, dead and maimed trafficking victims], it appears that the estimates of the U.S Diplomatic Mission to Nigeria that as of May 2003, as many as 300,000 [Nigerian women] have been trafficked since 1997" [8]. 
Most Nigerians are trafficked to various destinations in Europe and the United Kingdom. Many are often trafficked and re-trafficked to various owners before escaping or returning home. Similarly like many other women across the globe, they too are motivated by the opportunity of supporting their families with income from abroad, making connections through informal networks such as friends and relatives who eventually facilitate their trafficking. Once they arrive at their destination, these women are raped, beaten and humiliated into submission, ensuring they never try to escape. Their vulnerability is compounded by the fact that their passports and papers are taken away and kept by their traffickers, sealing their fate to a life of slavery. Through the representations of Eyo (Eyo), Sisi (On Black Sisters' Street), Efe (On Black Sisters' Street), Joyce (On Black Sisters' Street), Ama (On Black Sisters' Street), Nneoma (Trafficked) and Efe's (Trafficked) experience of trafficking, Nigerian women writers create for us an intricate web to understand the alarmingly systematic, highly regulated movement and exploitation of modern slavery.

Fig. 1. The concentric involvement of Nigerian women in global organized crime

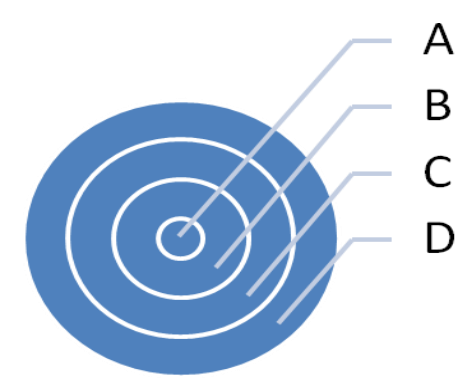

Fig. 1 illustrates the involvement of Nigerian women as resources for the global capitalist flesh trade and the role played by Nigerian women writers in revealing this social suffering. Set A represents women who are vulnerable targets to trafficking from their poverty stricken lives heightened with the implementation of structural adjustment programs which exacerbate their coercion into commercial sex by organized syndicates. Set B represents the local organized syndicate that recruits and sponsor these women's travel by forging passports, visas as well as the travel fare. Set C represents the international, global crime syndicates that trap Nigerian women through acts of violence to a subjugated life of slavery. Finally, Set D represents the role of Nigerian women writer's works in accounting for this social tragedy in order to raise public awareness. Thus it is vital for us to have this concentric understanding on the nature of sex trafficking and the essential role played by Nigerian women writers in exposing this horrendous crime.

\section{THE DYNAMICS OF TRAFFICKING IN NIGERIAN WOMEN'S WRITINGS: COMPLEX POWER RELATIONS AND RESISTANCE}

Exploitation through violent coercion and control is depicted in the works of Ezeigbo, Sanusi and Unigwe as the method used by traffickers to ensure submission and subjugation from their victims. In resistance to this male dominant ideology of power and control, Trafficked (2008), Eyo (2009) and On Black Sisters' Street (2009) reveals the economic, social and political factors that facilitate the oppression of women who are trafficked and how Nigerian female characters challenge the conditions of their lives as trafficked women, subverting existing relations of power. The female process from enslavement towards freedom mirrors Chikwenye Okonjo Ogunyemi and Alica Walker's womanist progression where victims of sex trafficking find ways to speak out and find a voice for themselves from liminal spaces, emerging with repertoires of skills that reflect tangible signs of personal freedom. Having articulated this, it is also vital for us to remember that the female process of empowerment is also fraught with ambivalence as these female characters face the similar challenges of poverty and disillusionment in their homecoming to Nigeria which can lead them back to the similar cycle of victimization.

Ezeigbo, Sanusi and Unigwe demonstrate how men in Nigeria use women as a form of commodity in their neo-liberal economy to gain personal wealth, which ultimately serve their own gratification. Their power is sustained through the reliance on the internalization by women of the tenets of slavery, submission and abuse "broken down through physical and psychological torture" [9]. When these women become trafficking victims, these "slaves are raped, tortured, starved, humiliated and drugged during their transportation, both for the pleasure of their traffickers and also to break the slaves to make them more submissive upon sale" [10]. Jorgen Carling on the other hand emphasizes that while "violent assault is undoubtedly common, [it is] neither a rule or a necessity in the Nigerian model of trafficking. The psychological control traffickers have over the women often makes violence unnecessary" [11]. The psychological hold traffickers have over their victims through threats against victims' families and their lives ensures obedience and submission. In each of the fictional texts by Ezeigbo, Sanusi and Unigwe, female characters are like pawns whose lives are orchestrated by brokers. Yet it is within these volatile experiences emerge the development of the female womanist through resistance. Chika Unigwe's On Black Sisters' Street (2009) tells us the stories of four African sex workers sharing an apartment in Antwerp's red light district. The dead Sisi in the text is the woman whose story in many ways is the most tragic, and the most telling for the premise of this argument. In the chapters that lead up to her death, Unigwe unfolds Sisi's story by interlacing her story with that of Efe, Joyce and Ama revealing the effect of a neo-colonial, neo-liberal Nigerian state to a promising, intelligent graduate like Sisi. Although Sisi was initially optimistic, imagining, looking forward to a realization of everything dreamed [...] a life different from her parents'[...] [that] University graduates [were] in high demand! High Demand! [...] Yet two years after leaving university, [she] was still mainly unemployed (she had done a three-month stint teaching economics at a holiday school; the principals of scarcity and want, Law of Supply and Demand) and had spent the better part of the two years scripting meticulous application letters and mailing them along with her résumé to the many different banks in Lagos [...] No envelopes came addressed to her, offering her a job in a bank 
considerably humbler than the banks she had eyed while at school, and in which less intelligent classmates with better connections worked." [12]

Sisi's life refers to the big questions that operate at a national and global level in regards to sex trafficking. Indicatively, Unigwe uses Sisi's narrative to embody the collective narratives of women who have been disembodied through violent subjugation and by hierarchies of local and international political and economical exploitation. Sisi's representation in the text can be used as a basis to reticulate the narrative representations of other Nigerian female characters like Eyo, Efe and Nneoma. Sisi's story reasserts the tragedy of a neo-colonial Nigerian state, where its leaders and their well connected boon companions who "[plunge] into the mire of corruption and pleasure" [13]. Hence, "for those who practise [neo-colonialism], it [meant] power without responsibility and for those who suffer from it, it [meant] exploitation without redress", the epitome of Sisi's life [14]. Unigwe unashamedly expresses the abject poverty and exploitation faced by the average Nigerian attempting to make a meager living, juxtaposing this reality with that of Dele's (the trafficker's) 'good' intentions of providing 'goods' for the supply and demand within entrenching economic liberalizations. The direct questioning of Nigeria's corrupt, masculine political leadership is targeted to the Obasanjo regime's multiple-forms of self-serving hypocrisy depicted by the prestigious and sophisticated lifestyles led by his family members, “Obasanjo's own children, were they being forced to do things just to survive? She had heard that they were at Ivy League universities in the US" [15]. Particularly useful to this discussion is the contrast created between Sisi's positioning and that of Obasanjo's children's positioning within societal structures. Although both sets of individuals have acquired an education, Sisi is placed within the circumferential location in society, forced into sex trafficking to survive. This location however becomes a hybrid breeding ground for resistance as Unigwe uses this volatile ground to create a self-claimed space for women who experience sex trafficking. Sisi's first act of resistance stems from her desire for change, to experience love and build a family with Luc. Her second step comes from her verbalizing Dele's exploitation and her refusal to no longer participate in her victimization. The final stage of Sisi's resistance happens in an in-between state of life and death, emphasizing freedom as well as vengeance. As "the hammer [hit] into her skull ... She was not yet dead when [...] in the instant between almost dying and stone-cold dead [...] Sisi's escaped her body and flew to Lagos [...]", to Dele her exploiter and facilitator of her murder [16]. This in-between space of resistance Sisi's spirit experiences, can be mirrored to that space which can be called a point zero stage ${ }^{1}$, very much like that space experienced by Nawal El Saadawi's Firdaus in Woman at Point Zero (1983) who uses her space as a locked up

\footnotetext{
${ }^{1}$ I also draw the idea of point zero subjectivity from the physics concep 'absolute zero' which describes the lowest temperature that is theoretically possible (-273celsius) where no movement happens. I use the metaphorical implication of this definition to describe how Nigerian women writers place male oppressors in immobile positions so that female characters may experience freedom through action and opposition.
}

prostitute waiting for execution in prison as a way of resisting the male discourse of exploitation and subjugation [17]. Similarly, in-between life and death, Sisi offers an impasse phase of reclaiming her life, refusing to be subjected to authority, cursing Dele in death through his children "'May your lives be bad. May you never enjoy love. May your father suffer as much as mine will when he hears I am gone. May you ruin him.' For Sisi was not the sort to forgive. Not even in death. Sisi's soul flew down the stairs and began its journey to another world" [18]. Although Sisi's triumph comes only in death unlike Ezeigbo's Efe and Sanusi's Eyo, her motivation towards claiming her subjectivity in her point zero experience depicts the female character's refusal to remain in liminal spaces.

Akachi Adimora-Ezeigbo's Nneoma and Efe in Trafficked (2008) mirror similar point zero accounts through their homecoming experience in Nigeria and attempt to renegotiate their space within society. The experience of assimilating back into society is one filled with uncertainty and trepidation for formerly trafficked women. The clinch point in Ezeigbo's text is the threat of re-trafficking experienced by Nneoma and Efe by the same syndicate Baron who was Nneoma's cruel pimp before her escape. Although Efe encounters Baron when she returns to Nigeria after being deported from trafficking, and is unwittingly attracted to him, she does not let her disappointment of Baron dissuade her from having a good life or neither does she immediately run away from him. Her anger compels her to action, "how dare he deceive her? The crook wanted to traffick her again. She would expose him and have him arrested!" [19]. Here, the female character refuses to remain silent and subjugated but is spurred towards engagement. Evidently, Efe's intent in challenging Baron stems from a desire for legal change, ensuring he gets arrested for the crimes he commits against women. Hence, Efe chooses to confront her 'prospective' oppressor and Nneoma's former exploiter in an open bar "Is your name truly Fyneface, or is it Baron [...] Baron's face twitched and fear filled his eyes. He thought Efe might be a detective or a member of the Secret Security Service [...] "You're a liar. You have lied to me all this while. You're Baron and a bloody trafficker. Her voice was loud and heads were beginning to turn [...] This man is a cheat and an exploiter. He is here to traffick women abroad" [20]. Unlike Sisi, who faces her oppressor in death, Efe and Nneoma both participate in resisting Baron in this point zero space of reality where the oppressor is forced to remain stagnant while the female character achieves her goal of 'objectifying' the trafficker, subverting his privileged position of power, rejecting authority. By doing this, Ezeigbo not only reveals to us the continuous cycle of trafficking syndicates but she also aptly creates an intersecting space within fiction to contest what cannot be said directly to these exploiters, again challenging the privileged position of existing relations of power by propositioning her own authoritative voice. Ezeigbo's Efe challenges presumptions that formerly trafficked women run away from threats of being re-trafficked. In fact, many victims of sex trafficking refuse to testify against their enslavers for fear of repercussion against themselves and their family members. Although Nneoma is initially reluctant to participate in Efe's 
fight for subjectivity, Efe's resolve for justice does not waver. Her confrontation with Baron marks a key element through fiction on how trafficked women need to take stock of their lives and fight to right what is wrongly done unto them. Efe's zeal to redress the threat of being re-trafficked highlights her womanist behavior of willfulness (Walker) that desires a curbing of female deception. Her indignation ties in closely with the unacceptable, ruthless 'business' of trafficking and re-trafficking women [21]. Her womanist determination to make a difference is Ezeigbo's method of highlighting the importance of a trafficked individual's quest for subjectivity and authority against preexisting trafficking systems of victimization.

Fig. 2. Female characters and male traffickers: An outline of characters in eyo (2009), trafficked (2008) and on black sisters' street (2009)

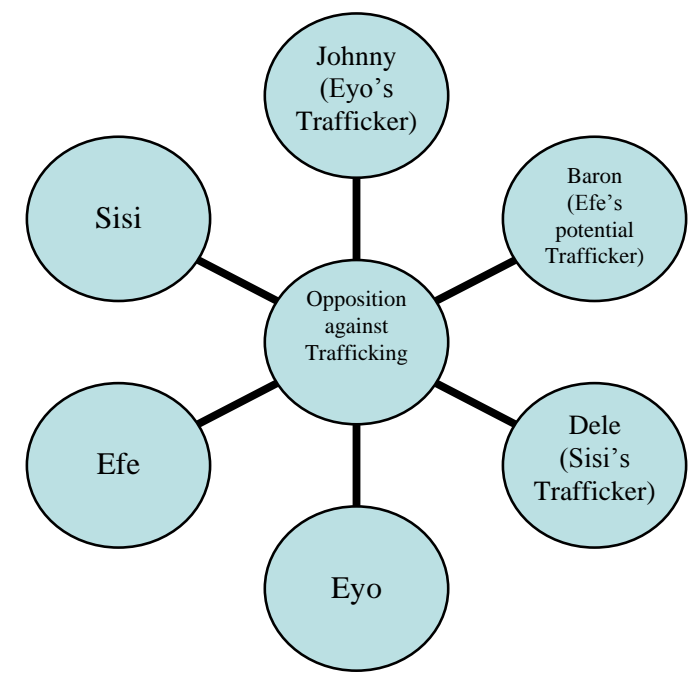

Fig. 2 gives us an outline on the names of characters involved in each of these texts, either as traffickers or trafficking victims. We find that the characters of Eyo, Efe and Sisi are juxtaposed against Johnny, Baron and Dele showing their clear opposition against trafficking. This binary demarcation of characters in the diagram (Eyo versus Johnny, Sisi versus Dele and Efe versus Baron) helps us understand the individual oppositions depicted in each of these individual texts.

On the other hand, Abidemi Sanusi's Eyo (2009) continues in the pattern of counteraction through physical aggression. Eyo's resistance surfaces in the text when her oppressors least expects it, when it is assumed that "any spiritedness left in the women would've have been broken by his fists and particular brand of sexual gratification" [22]. Eyo often swore to herself that "she would pay [Johnny] back for this and every beating" [23]. After experiencing numerous forms of abuse, from rape, abortion to performing sexual acts with multiple men and an animal on camera, Eyo's anger is deflected back to her pimp in his sleep as "she came back into the flat, she was holding a baseball bat [...] She advanced towards the bed with the baseball bat firmly in her hands. She lifted up her hands and brought the bat down hard on Johnny's face. And she didn't stop" [24]. Interestingly, in this point zero moment, the male aggressor is placed in a silent submissive position of sleep, no movement, while the female position from liminality is empowered to action. Eyo is able to assert her opposition and claim her freedom through physical opposition. However, while Eyo's narrative of resistance ends on a note of ambivalence with her returning to trafficking, one cannot help but see the point further driven home by Sanusi that the state of the Nigerian neo-liberal economy is unable to sustain its people, where women have no choice but to be a part of its 'goods'. The harsh reality of Eyo's circumstances carves an unforgettable reminder of Nigeria's socio-economic impoverishment.

Undoubtedly however, the womanist character's development from menarche and an epiphany (Ogunyemi) while recognizing her commitment to society (Walker) is depicted collectively by these female characters as they develop into womanist characters who through their words and actions rebel against the female experience of silencing, domination and subjugation [21]. Here, we may extend womanist theory to include this 'point zero' space to the developmental process of the womanist, to recognize the location where aspects of resistance are experienced. Eyo, Sisi, Nneoma and Efe's womanist characters are platforms used to articulate continuous opposition, action and aversion towards sex trafficking. The point zero space facilitates their acts of freedom, confirming the womanist character's strong willfulness, agency and subjectivity. In each of their responses, depicted in their point zero space, Eyo, Sisi and Efe reflect the need to break the chains of sex slavery that incarcerate women mercilessly. This need evidently rises from a womanist manifesto that encourages willful and strong behavior amidst oppression and subjugation. It draws from a female determination to reject exploitation and injustice, to re-stake female boundaries that have been crossed. In this way, the representation of Nigerian female characters builds a literary framework for individual abolition of sex slavery through resolute characters who long to see an end to the dehumanization of women. This in turn encourages the reader to take active steps to reevaluate our perception on what constitutes sex trafficking through understanding the trauma victims of this form of slavery suffer. As such, the works of Nigerian women writers gear society towards making necessary changes since proper legislation has not been established amongst the nations to end the horror of trafficking.

Fig. 3. The complex power relations between the victim and victimizeraction and opposition which develops point zero subjectivity

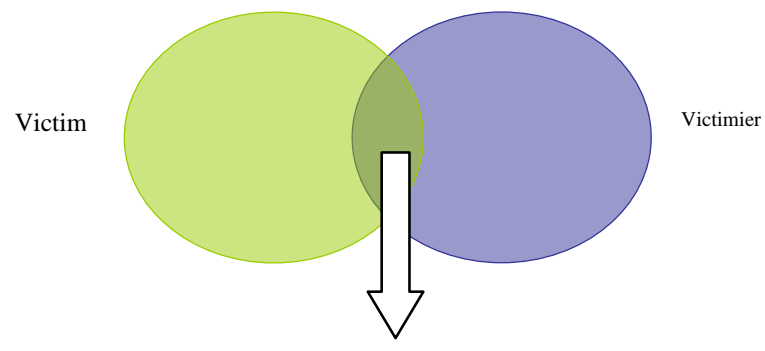

Point zero subjectivity through action and opposition 
Fig. 3 depicts the point zero space of subjectivity where female characters challenge their victimizers through action and opposition to achieve agency and self-determination. The overlapping space between victim and victimizer is achieved when the female character chooses to no longer accept subjugation and abuse. This resolution space becomes a hybrid inducement where female characters are compelled to confront and question the inhumane acts of traffickers. Thus, the role of Nigerian women's writings is vital in creating an opening within fiction to articulate the dynamics of sex trafficking.

\section{CONCLUSION}

In a compassionate engagement with issues of sex trafficking, it is vital for us to recognize the role of Nigerian women writers in using literature as a basis to establish the fundamental socio-economic and political issues that plague Nigeria today, the representation of Nigerian female stories that signify experiential truths. The framework that paramount's the 'business' of modern slavery today is very much like that which dominated the Atlantic slave trade 350 years ago. Yet, while there was then the existence of the Underground Railroad of freedom to assist the abolition of slavery, this is today replaced by an underground criminal network that entraps and sells people into slavery. This indeed is a tragic paradox in our time, one which continues to be a hidden crime. Yet the core focus of our discussion here has been to analyse the fundamental characteristics and resistance shown by the enslaved person's life through Sanusi, Ezeigbo and Unigwe's writings, a conglomeration of literary works of protest that function as a clarion call to end the dehumanization of Nigerian women through sex trafficking.

\section{REFERENCES}

[1] S. Kara and Sex Trafficking: The Inside Business of Modern Slavery, New York, U.S: Columbia University Press, 2009, pp. 260.

[2] J. Carling, Migration, Human Smuggling, and Trafficking from Nigeria to Europe, Oslo, Norway: International Peace Research Institute, 2006, pp. 45.

[3] Ed., L. Philips, The Womanist Reader, New York, U.K: Routledge, 2006, pp.47.

[4] S. Kara, Sex Trafficking: The Inside Business of Modern Slavery, New York, U.S: Columbia University Press, 2009, pp. 260.

[5] J. Carling, migration, human smuggling and trafficking from Nigeria to Europe, Oslo, Norway: International Peace Research Institute, 2006, pp. 55 .
[6] S. Kara, Sex Trafficking: The Inside Business of Modern Slavery, New York, U.S: Columbia University Press, 2009, pp. 19-22.

[7] V. N. Opara, "Emerging issues in the trafficking of African women for prostitution," Toyin Falola and Niyi Afolabi, The Human Cost of African Migration New York, U.S: Routledge, 2007, pp.170.

[8] V. N. Opara, "Emerging issues in the trafficking of African women for prostitution," Toyin Falola and Niyi Afolabi, The Human Cost of African Migration New York, U.S: Routledge, 2007, pp.172.

[9] S. Kara, Sex Trafficking: The Inside Business of Modern Slavery, New York, U.S: Columbia University Press, 2009, pp. 3.

[10] S. Kara, Sex Trafficking: The Inside Business of Modern Slavery, New York, U.S: Columbia University Press, 2009, pp. 12.

[11] J. Carling, migration, human smuggling and trafficking from Nigeria to Europe, Oslo, Norway: International Peace Research Institute, 2006, pp. 48.

[12] C. Unigwe, On Black Sisters' Street, London, U.K: Jonathan Cape, 2009, pp. 18-22.

[13] F. Fanon, The Wretched of the Earth, Harmondsworth: Penguin, 1967, pp. 134.

[14] K. Nkrumah, Africa Must Unite, London. U.K: Heinemann, 1963, pp. $\mathrm{xi}$.

[15] C. Unigwe, On Black Sisters' Street, London, U.K: Jonathan Cape, 2009 , pp. 293

[16] N. El-Saadawi, Woman at Point Zero, London, U.K: Zed Books Ltd, 1975.

[17] C. Unigwe, On Black Sisters' Street, London, U.K: Jonathan Cape, 2009 , pp. 296

[18] A. Adimora-Ezeigbo, Trafficked, Lagos, Nigeria: Lantern Books, 2008, pp 186.

[19] A. Adimora-Ezeigbo, Trafficked, Lagos, Nigeria: Lantern Books, 2008, pp 186-187.

[20] Ed., L. Philips, The Womanist Reader, New York, U.K: Routledge, 2006.

[21] A. Sanusi, Eyo, Nairobi, Kenya: WordAlive Publishers Limited, 2009, pp. 199.

[22] A. Sanusi, Eyo, Nairobi, Kenya: WordAlive Publishers Limited, 2009, pp. 209

[23] A. Sanusi, Eyo, Nairobi, Kenya: WordAlive Publishers Limited, 2009, pp. 238.

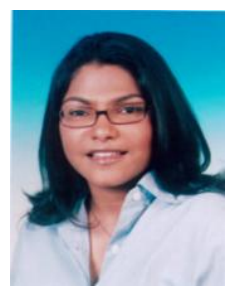

Shalini Nadaswaran is currently a $\mathrm{PhD}$ candidate at the School of English, Media and Performing Arts, Sydney, Australia. She is also under a fellowship scheme with her alma mater, the Department of English, University of Malaya, Kuala Lumpur, Malaysia. She received her Bachelor's and Master's degree in Literature from the University of Malaya in 2003 and 2007 respectively. Her current research specialization is in African women's literature where she focuses on the changing role of Nigerian women in family and nation. Her journal article "Rethinking Family Relationships in Third-Generation Nigerian Women's Fiction” published by Revue electronique de litterature francaise RELIEF (http://www.revue-relief.org/index.php/relief/article/viewFile/652/730) focuses on this aspect of change. Her larger research interest lies in understanding the constant evolving representations of women in local and global spaces. 